American Journal of Animal and Veterinary Sciences 6 (1): 31-34, 2011

ISSN 1557-4555

(C) 2011 Science Publications

\title{
Effect of Intramammary Injection of Nigella Sativa on Somatic Cell Count and Staphylococcus Aureus Count in Holstein Cows with S. aureus Subclinical Mastitis
}

\author{
${ }^{1}$ Hamideh Ghodrati Azadi, ${ }^{2}$ Nima Farzaneh, ${ }^{2}$ Zahra Baghestani, \\ ${ }^{2}$ Azam Mohamadi and ${ }^{3}$ Seyed Ali Mahdavi Shahri \\ ${ }^{1}$ Department of Basic Sciences, Faculty of Veterinary Medicine, \\ ${ }^{2}$ Department of Clinical Sciences, Faculty of Veterinary Medicine, \\ ${ }^{3}$ Department of animal Sciences College of Agriculture, \\ Ferdowsi University of Mashhad, Mashhad, Iran
}

\begin{abstract}
Problem statement: The seeds of Nigella sativa Linn. (Ranunculaceae) known as black seed or black cumin, are used in herbal medicine all over the world for the treatment and prevention of a number of diseases and conditions that include asthma, diarrhea and dyslipidaemia. Approach: In this study the effect of intramammary injection of Nigella Sativa Extract (NSE) in paraffin on quarter milk, quality and Somatic Cell Count (SCC) and the shedding pattern of Staphylococcus aureus were investigated. Thirty Holstein cows, naturally infected with $S$. aureus subclinical mastitis, were subjected to treatment with the NSE at a dose of $10 \mathrm{~mL}$ in paraffin $\left(200 \mathrm{mg} \mathrm{mL}^{-1}\right)$ per day for 3 days, or with $10 \mathrm{~mL}$ paraffin as control. The injection areas were checked for adverse reactions. The daily milk production was measured before and after treatment. Intramammary injection of NSE caused a remarkable healing. Quarter milk samples were collected for bacteriological analysis and Somatic Cell Counts (SCC). The bacterial count moderately decreased in the treatment group. After the end of the treatment, the numbers of S. aureus-infected quarters and milk SCC tended to decrease in the NSEtreated cows. These clarifications were significantly higher one week post-treatment than pretreatment. Similar changes were not observed in the control group. Results: The results of the present study showed that the NSE has potential as a therapeutic agent for S. aureus infection causing subclinical mastitis of dairy cows and may contribute to the cow's recovery from mastitis. Conclusion: In conclusion, the results indicate that Nigella sativa might act as an antibacterial in vivo in dairy cows.
\end{abstract}

Key words: Subclinical Mastitis, Nigella sativa, antimicrobial effects, Mashhad

\section{INTRODUCTION}

Staphylococcus aureus mastitis is known to be highly resistant to antibiotic therapy. The organism forms microabscesses or granulomas in the mammary gland tissues, survives in the host's cells and becomes chronic quite easily (Azadi and Farzaneh, 2010). Due to the poor response of $S$. aureus to antibiotic therapy, as well as the risk of antibiotic residues in milk, chemotherapy is usually not recommended during the lactating period (Gruet et al., 2001). Thus, various treatment methods that are not dependent on antibiotics in studies on the prevention and treatment of mastitis have been tried.

The main finding during subclinical mastitis in dairy cows is the elevated milk Somatic Cell Count (SCC). Subclinical mastitis leads to a decrease in both milk quality and production, by far, it is the most prevalent form of mastitis world-wide in dairy cattle (Hu et al., 2001). The most common bacteriological finding is $S$. aureus, which is detected in approximately $40 \%$ of bacteriological positive subclinical cases of mastitis (Wilson et al., 1999). Furthermore, antibiotic therapy can also inhibit the normal defense mechanisms of the host by decreasing phagocytes function and thereby further exacerbating the inefficiency of the phagocytes and subsequent relapse of the infection (Aboul-Ela., 2002). Nigella sativa has been used as a natural medicine in China for thousands of years for multiple therapeutic purposes in both humans and animals (Lai and Roy, 2004). The results of a study revealed clear potentiality of $N$. sativa fixed oil as a source for anti-microbial drugs and support its use in

Corresponding Author: Hamideh Ghodrati Azadi, Department of Basic Sciences, Faculty of Veterinary Medicine, Ferdowsi University of Mashhad, Mashhad, Iran 
folk medicine for the treatment of microbial skin infections (Abu-Al-Basalc, 2009).

Therefore, the present study was performed to investigate the effect of intramammary injection of Nigella sativa on infected cows with subclinical mastitis as a result of spontaneous infection with $S$. aureus.

\section{MATERIALS AND METHODS}

One hundred and ten Holstein milking cows of the Mashhad University dairy farm near Mohamadabad was used to evaluate the NSE. Cows with milk SCC more than 200,000 cells $\mathrm{mL}^{1}$ were enrolled in the study based on positive California Mastitis Test (CMT) and isolation of the same mastitis pathogen in 2 samplings performed with 1 week intervals. Cows with the $S$. aureus subclinical intramammary infection were blocked by parity and Days In Milk (DIM) and allocated randomly to the treatment and control groups. Sixty four quarters with $S$. aureus subclinical mastitis were tested.

They had all been shown to have at least one quarter subclinically $S$. aureus-infected and elevated milk somatic cell counts by repeated sampling and culturing. The cows had been lactating for $5 \pm 9$ months and were milked 3 times daily throughout the study. The average daily milk production was $30 \mathrm{~kg}$ at the start of the experiment.

Nigella Sativa Extract in Paraffin (NSE) was prepared by dissolving $2 \mathrm{~kg}$ of the Nigella sativa powder in 10 liters of paraffin. After $24 \mathrm{~h}$ the solution was filtered and sterilized by autoclaving as a final concentration of $200 \mathrm{mg}$ Nigella sativa per $\mathrm{ml}$ and then sealed in sterilized $250 \mathrm{~mL}$ glass bottles (Nigella sativa equivalent at a dose of $10 \mathrm{~mL}, 200 \mathrm{mg} \mathrm{mL}^{1}$ in paraffin). No bacterial growth was detected after the solution was inoculated on blood agar plates and cultured overnight at $37^{\circ} \mathrm{C}$. The solution was prepared 3 weeks before the start of the experiment and stored at room temperature.

The study was initiated May 21, 2009 and concluded December 15, 2009. Average room temperature at the morning sampling time (08:00) during the experimental period was $23 \pm 2{ }^{\circ} \mathrm{C}$.

Thirty Holstein dairy cows in their second to third lactation were selected in the main experiment out of a total of 110 cows. The test was conducted to investigate the effects of $2 \mathrm{~g} / 10 \mathrm{~mL}$ of the Nigella sativa extract on the milk parameters, including milk SCC and S. aureus count. The cows were all in mid-lactation (156 days) and were milked three times daily throughout the study. The mean \pm standard deviation of the body weight of cows was $595 \pm 25 \mathrm{~kg}$ in both groups of cows. The cows did not have clinical mastitis, but at least one quarter was subclinically and spontaneously infected with S. aureus and had elevated milk SCC (above 200,000 cells $\mathrm{mL}^{1}$ ). We confirmed that the mastitis was $S$. aureus-induced by performing weekly subclinical cultures, SCC and cultures of total bacteria and $S$. aureus prior to the experiment.

The cows were randomly divided into two groups: (1) the Nigella sativa-treated group $(\mathrm{n}=30)$, in which each cow was given intramammary injections with the Nigella sativa sterile extract (at a dose of $2 \mathrm{~g}$ in $10 \mathrm{~mL}$ paraffin) once daily for 3 days. This dose was selected on the basis of previous research (3). The control group $(n=30)$ cows received daily intramammary injections of pure sterile paraffin solution at a dose of $10 \mathrm{~mL}$ for 3 days. The injection areas were checked for adverse reactions every day during the treatment period. The daily milk production was measured both before and after the treatment. All milk samples were collected prior to the morning milking. Samples were from the start of treatments, 3 day and at one week after the end of the treatments for both the control and the experimental treatments. Quarter milk samples were aseptically collected for bacteriological analysis and SCC.

Approximately $10 \mathrm{~mL}$ of milk was taken at each sampling interval. The samples were collected from cows kept in stanchion stalls with ice. Rectal temperature was measured at the time of milk sampling using a mercury thermometer and it was $38 \pm 0.5$. Daily milk yield was calculated as the sum of noon (11:30) SCC and the counts of total bacteria, S. aureus, were measured in order to evaluate the therapeutic effect of NSE.

For the bacteriological examination of the milk samples and the analysis of bacterial growth, milk samples were inoculated on blood agar plates incubated for 24 and $48 \mathrm{~h}$ at $37^{\circ} \mathrm{C}$. After incubation, bacterial growth was scored as I ( $9 \pm 1 S$. aureus colonies), II (50 $\pm 10 \mathrm{~S}$. aureus colonies) and III (>50 S. aureus colonies) according to routines at the Department of Mastitis, Faculty of Veterinary Medicine, Mashhad, Iran.

All results are expressed as mean \pm SEM. Significance of difference from the value at the preinjection time of each solution in each group was determined by paired t-test. So, to determine the normality of each group, the one sample KolmogorovSmirnov test was used to compare milk bacterial growth scores between the two groups for each sampling occasion and the scores between pretreatment and after treatment in each group. The pretreatment values for each cow or udder quarter were calculated. Then, this pre-treatment value and each 
post-treatment value within each cow or udder quarter were compared by paired t-test. Thereafter, for each parameter, the change between the pre-treatment value and the value on each post-treatment sampling was calculated. The changes in the treatment and the control groups were compared by the two independent sample t-tests. The results are presented as means \pm SD. Probabilities less than 0.01 were considered significant.

\section{RESULTS}

For the main experiment, $10 \mathrm{~mL}$ of $200 \mathrm{mg} \mathrm{mL}^{-1}$ of Nigella sativa extract was employed. Milk S. aureus count had decreased responses after injections of NSE, clinical signs and daily milk yield. None of the cows in treatment group showed any abnormal clinical symptoms or any visible local reactions in the areas injected with the control or the NSE.

Feed intake was unchanged throughout the experiments in both groups. The daily milk production in none of groups improved after treatment and no significant difference was observed between the treatment group and the control, indicating that the treatment has no effect on enhancing the milk yield. Bacterial counts in the milk (Fig. 1) indicated a change in milk SCC following the injections of paraffin (control) and NSE (treatment) and reduced the bulk milk SCC from 245,000-218,000 cells $\mathrm{mL}^{-1}$ in the treatment group (the values at 0 , days 3 and 7 ). The counts were significantly lowered $(p<0.01)$ by the NSE, meaning the NSE effect on SCC between days 0 and 3 and also days 3 and 7 . And the counts were greater ( $p>0.01$ ) by the paraffin, meaning paraffin has no effect on SCC between days 0 and 3 and also days 3 and 7 .

Each point and vertical bar represents the mean \pm SD of 30 animals. Significance of difference from the value at the pre-injection time of each solution in each group is indicated as bacterial counts in the milk. The results of the bacteriological analysis of the milk samples are shown in Table 1. It indicates the total bacterial count following intramammary administrations of the control and the NSE. The count was significantly lowered $(\mathrm{p}<0.01)$ by the difference of treatment and control, which means the average of the treatment SCC is lower than the average of the control SCC. Obviously, this fact is observed in Fig. 1. None of the cows showed any abnormal clinical symptoms or any visible local reactions in the areas injected with the NSE or the paraffin solution.

Milk samples from 120 quarters (30 cows) in each group were examined. 64 quarters in the NSE treated cows and 48 quarters in the control cows were infected with $S$. aureus before treatment. After the Nigella sativa treatment, 23 quarters were bacteriological negative at all samplings, whereas in 41 quarters S. aureus was detected only at the sampling one week after the end of the treatment. Thus, the number of $S$. aureus-infected mammary glands decreased from 64 to 41 in the Nigella sativa-treated group. Moreover, two new $S$. aureus infections were detected in one udder quarter. Therefore, the total number of infected quarters increased from 41 to 43 . In the control cows, S. aureus was detected in the initially infected quarters at almost all examinations after paraffin.

The milk SCC tended to decrease in the infected quarters in the Nigella sativa treated cows as shown in Fig. 1, but the change within the group was not statistically significant. The SCC in the control cows did not change during the experimental period. The changes from pretreatment to post-treatment did not differ significantly between the two groups of control at any time point. Total bacterial counts in the milk of the treatment group on days 0,3 and 7 were 64, 42 and 43, respectively. At the end of the study bacteriological cure rates were 34.4 and $33 \%$, days 3 and 7 respectively. The E. coli count in the milk was under the detection limit throughout the experiment.

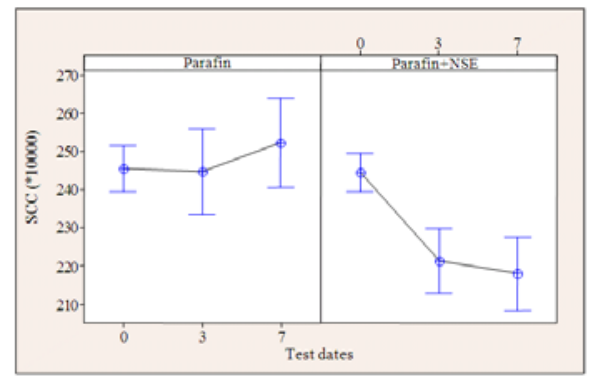

Fig. 1: Change in somatic cell count following intramammary injections of control (Paraffin) and Nigella Sativa Extract (NSE) in subclinical mastitis group

Table 1: Number of quarters infected with Staphylococcus aureus and bacterial growth score, before and after intramammary injection with Nigella sativa or Paraffin solution $(\mathrm{n}=30$ cows; 120 examined quarters)

\begin{tabular}{|c|c|c|c|c|}
\hline \multirow[b]{2}{*}{ Treatment } & \multirow{2}{*}{$\begin{array}{l}\text { Bacterial } \\
\text { growth } \\
\text { score } *\end{array}$} & \multicolumn{3}{|c|}{$\begin{array}{l}\text { Numbers of infected } \\
\text { quarters after treatment }\end{array}$} \\
\hline & & 0 day & 3 days & 1 weeks \\
\hline \multirow[t]{3}{*}{ Nigella sativa } & $\mathrm{I}$ & 27 & 13 & 14 \\
\hline & II & 31 & 20 & 20 \\
\hline & III & 6 & 9 & 9 \\
\hline Total infected quarters & & 64 & 42 & 43 \\
\hline \multirow[t]{3}{*}{ Paraffin } & I & 23 & 20 & 20 \\
\hline & II & 22 & 19 & 19 \\
\hline & III & 3 & 5 & 5 \\
\hline Total infected quarters & & 48 & 44 & 44 \\
\hline
\end{tabular}




\section{DISCUSSION}

Although the current antibiotic therapy can be effective in the control of some microbe-induced mastitis, the therapy of $S$. aureus mastitis is only moderately efficacious and because of antibiotic residues requires a 3-5-day milk withdrawal (Gruet et al., 2001; Hu et al., 2001). The Nigella sativa extract used in the present study was also proven safe to use in the dairy cow as no adverse reactions were found at the injection sites, nor any other side-effects during the Nigella sativa treatment (Sharma et al., 2009).

In the present study, injections of Nigella sativa extract resulted in a tendency of bacterial growth to decrease. Consistent with our findings, (Azadi and Farzaneh, 2010) showed that milk SCC of the quarters infected with $S$. aureus decreased after injection of Nigella sativa extract. Also findings suggest an increased resistance to $S$. aureus infection in the udder after Nigella sativa treatment (Wall et al., 2005). The usefulness of the treatment trials could be improved by the standardization of case definitions, consideration of the host and strain factors and sufficient statistical power (Wall et al., 2005; Barkema et al., 2006; Heringstad et al., 2000).

\section{CONCLUSION}

In conclusion, the results indicate that Nigella sativa might act as an antibacterial in vivo in dairy cows. The study included only a small number of animals, more investigations are needed to clarify the effects of Nigella sativa in cows.

\section{ACKNOWLEDGEMENT}

This study was supported by a research fund of Ferdowsi University of Mashhad, Iran (project No: $12490,83 / 3 / 20$ ).

\section{REFERENCES}

Aboul-Ela, E.I., 2002. Cytogenetic studies on Nigella sativa seeds extract and thymoquinone on mouse cells infected with schistosomiasis using karyotyping. Mutation Res. /Genetic Toxicol. Environ. Mutage., 516: 11-17 DOI: 10.1016/S1383-5718(01)00333-3
Abu-Al-Basalc, M.A., 2009. In vitro and In vivo antimicrobial effects of nigella sativa linn. seed extracts against clinical isolates from skin wound infections. Am. J. Applied Sci., 6: 1440-1447. DOI: 10.3844/ajassp.2009.1440.1447

Azadi, H.G. and N. Farzaneh, 2010. Comparison of two regimens of nigella sativa extract for treatment of subclinical mastitis caused by staphylococcus aureus. Am. J. Applied Sci., 7: 1210-1214. DOI: 10.3844/ajassp.2010.1210.1214

Barkema, H.W., Y.H. Schukken and R.N. Zadoks, 2006. Invited review: The role of cow, pathogen, and treatment regimen in the therapeutic success of bovine Staphylococcus aureus mastitis. J. Dairy Sci., 89: 1877-1895. DOI: $10.3168 /$ jds.S00220302(06)72256-1

Gruet, P., P. Maincent, X. Berthelot and V. Kaltsatos, 2001. Bovine mastitis and intramammary drug delivery: Review and perspectives. Adv. Drug Deliv. Rev., 50: 245-259. DOI: 10.1016/S0169409X(01)00160-0

Heringstad, B., G. Klemetsdal and J. Ruane, 2000. Selection for mastitis resistance in dairy cattle: A review with focus on the situation in the Nordic countries. Livest. Prod. Sci., 64: 95-106. DOI: 10.1016/S0301-6226(99)00128-1

Hu, S., C. Concha, A. Johannisson, G. Meglia and K.P. Waller, 2001. Effect of subcutaneous injection of ginseng on cows with subclinical Staphylococcus aureus mastitis. J. Vet. Med., 48: 519-528. DOI: $10.1111 / \mathrm{j} .1439-0450.2001 .00470 . x$

Lai, P.K. and J. Roy, 2004. Antimicrobial and chemopreventive properties of herbs and spices. Curr. Med. Chem., 11: 1451-1460. PMID: 15180577

Sharma, N.K., D. Ahirwar, D. Jhade and S. Gupta, 2009. Medicinal and phamacological potential of nigella sativa: A review. Ethnobotanical Rev., 13: 946-955.

Wall, R.J., A.M. Powell, M.J. Paape, D.E. Kerr and D.D. Bannerman et al., 2005. Genetically enhanced cows resist intramammary Staphylococcus aureus infection. Nat. Biotechnol., 23: 445-451. DOI: $10.1038 / \mathrm{nbt} 1078$

Wilson, D.J., R.N. Gonzalez, K.L. Case, L.L. Garrison and Y.T. Groohn, 1999. Comparison of seven antibiotic treatments with no treatment for bacteriological efficacy against bovine mastitis pathogens. J. Dairy Sci., 82: 1664-1670. DOI: 10.3168/jds.S0022-0302(99)75395 